\title{
PRZESŁANIA JANA PAWLA II DO LEKARZY O PRAWIE KAŻDEgO CZŁOWIEKA DO OCHRONY ŻYCIA I ZDROWIA
}

Moją wypowiedź można traktować jedynie jako fragment bardzo szerokiej dyskusji na temat wciąż aktualnych rozważań Jana Pawła II o roli medycyny i środowiska medycznego w procesach ochrony zdrowia i życia człowieka od jego poczęcia do naturalnej śmierci.

Z tego względu ograniczę się do przedstawienia niektórych tylko, jak sądzę ważnych, aspektów tego zagadnienia oraz kilku wydarzeń mających miejsce w okresie pontyfikatu papieża, a mianowicie:

- tworzenia podstaw współpracy między służbą zdrowia a duszpasterstwem chorych,

- wpływu nauk Jana Pawła II na procesy przywracania medycynie jej ludzkiego oblicza,

- prawa do wolnego sumienia w praktyce lekarskiej.

Dziś coraz powszechniej doceniane są prorockie wypowiedzi papieża o niebezpiecznym dla naszej cywilizacji odchodzeniu od biologicznych podstaw życia ludzkiego.

W opracowaniu tego tematu oparłem się przede wszystkim na oryginalnych wypowiedziach Jana Pawła II, korzystając z istniejących publikacji, m.in. prof. dr. Jerzego Woy-Wojciechowskiego, dr med. Grażyny Rybak, prof. dr. Zdzisława Ryna, a także na dokumenach Papieskiej Akademii Pro Vita, której członkiem byłem od chwili jej powołania ${ }^{1}$.

1 Por. J. Woy-Wojciechowski, Jan Paweł II i medycyna, Warszawa 2007; Jan Paweł II: Być lekarzem, by ulżyć cierpieniu bliźniego, wybór i oprac. G. Rybak, Warszawa 2011; Cierpienie ma tysiąc twarzy. Jan Pawet II i chorzy, oprac. Z. Ryn, Kraków 1988; Z. Chłap, Polskie poczatki Papieskiej Akademii „Pro Vita”, [w:] Bioetyka pokolenia Karola Wojtyły - Jana Pawła II. Materiały z Ogólnopolskiej Interdyscyplinarnej Konferencji 14 stycznia 2012 roku, red. A. Muszala, T. Kraj, P. Zielonka-Rduch, Kraków-Łagiewniki 2013, s. 71-81. 
Wspominam o tym na wstępie, ponieważ w historii papiestwa nieznanym fenomenem jest tak wszechstronne i głębokie zainteresowanie papieża udziałem środowiska lekarskiego w ochronie życia i zdrowia człowieka.

W okresie pontyfikatu Jana Pawła II, jak podają biografowie, zarejestrowano ponad 130 audiencji, spotkań z lekarzami i pielęgniarkami, zanotowano, że papież odbył 64 wizyty w szpitalach oraz brał udział w blisko 120 specjalnych spotkaniach z chorymi, niepełnosprawnymi, zwłaszcza z dziećmi. Służby kościelne podają, że ojciec święty osobiście odprawił kilkadziesiąt mszy świętych w intencji chorych, cierpiących, także ludzi starych, samotnych, ubogich. Do tej „arytmetyki” niezwykłego zainteresowania Jana Pawła II medycyną dodam tylko, że w ciągu jednego tylko roku Jan Paweł II napisał 1800 stron publikacji dotyczących ochrony życia człowieka².

Niewątpliwie najbogatszym źródłem odniesień papieża do roli środowiska lekarskiego są dzieła o ogólnoludzkich wartościach, przede wszystkim Ewangelie. Przypominają one lekarzom, zwłaszcza katolikom, że wśród motywów postępowania lekarskiego elementem niesłychanie ważnym i obligującym, choć nie zawsze uświadamianym sobie, jest: m ił o s i e rd zi e.

Na jednym ze Zjazdów Lekarzy w 1979 roku Jan Paweł II powiedział: „Waszym powołaniem jest inaczej miłować człowieka, pełniej miłować człowieka. Miłować go tam, gdzie już inni miłować nie potrafią"”.

W 1978 roku (w czasie Kongresu Włoskich Lekarzy Katolickich) mówił natomiast: „Papież chętnie przyłącza się do lekarzy o prawym sumieniu i czyni swoimi ich zasadnicze zadania [...], aby przede wszystkim uznano za najistotniejsze w ich zawodzie, że są sługami życia, nigdy zaś nosicielami śmierci”4.

Jest to dla nas jedna $\mathrm{z}$ najważniejszych wypowiedzi, poruszająca osobistym zaangażowaniem papieża, zapewniająca o jego wsparciu służby zdrowia jako „sojuszników dzieła”. Jest też w tym krótkim wystąpieniu zapowiedź tworzenia przez Jana Pawła II instytucjonalnego przymierza medycyny z posłannictwem Kościoła w ochronie człowieka 5 .

Jednym z bardzo cennych doświadczeń dla przyszłego papieża, a wówczas młodego wikariusza parafii św. Floriana w Krakowie, było nieoczekiwane powierzenie mu przez księcia kardynała Adama Sapiehę duszpasterstwa chorych, opartego

2 Por. J. Woy-Wojciechowski, Jan Paweł II i medycyna, dz. cyt., s. 129.

3 Bp T. Rakoczy, Przedmowa, [w:] J. Woy-Wojciechowski, Jan Paweł II i medycyna, dz. cyt., s. 12.

${ }^{4}$ Jan Paweł II, Do włoskich lekarzy katolickich, 28.12.1978, [w:] Jan Paweł II: Być lekarzem..., dz. cyt., s. 42.

5 Por. Z. Chłap, Przymierza medycyny dla ochrony człowieka $w$ duchu „Evangelium vitae” (wykład wygłoszony 20 lutego 1996 w ramach konwersatorium Instytutu Jana Pawła II KUL), [w:] Jan Paweł II, Evangelium Vitae. Tekst i komentarze, red. T. Styczeń SDS, J. Nagórny, Lublin 1997, s. 365. 
o wolontariat osób świeckich. Prawdopodobnie już wtedy zrodziła się myśl tworzenia i umacniania na całym świecie przymierza środowiska lekarskiego z posłannictwem Kościoła w ochronie godności życia każdego człowieka.

Wielką pomocą w działalności duszpasterskiej i nauczycielskiej papieża była znajomość problemów osobowości człowieka. Tymi zagadnieniami szczególnie zajmował się on na Katolickim Uniwersytecie w Lublinie. Dotyczyły one kwestii antropologii i teologii osoby w jej psychofizycznej immanentnej i transcendentnej postaci.

W oparciu o te studia papież „radykalnie sprzeciwia się «redukcjonizmowi typu przyrodniczego», o konotacji marksistowskiej, rozwijając w sposób komplementarny koncepcję «antropologii adekwatnej», i «hermeneutyki teologicznej»". Później dodaje:

[...] jesteśmy dziećmi epoki, w której ta integralna wizja człowieka w wyniku postępu wielu nauk z łatwością może być wyparta i zastąpiona przez różne ujęcia cząstkowe, które nie dosięgają integrum człowieka lub pozostawiają je poza swoim polem widzenia.

Fragment ten cytuję za ks. abp. dr. med. Henrykiem Hozerem, który uważa, że powyższe stwierdzenie odgrywa fundamentalną rolę we współczesnej debacie bioetycznej ${ }^{6}$.

To wizjonerskie spojrzenie Jana Pawła II dotyczące współczesnych i przyszłych niebezpieczeństw w odchodzeniu od integralnego pojmowania osoby ludzkiej powinno być przestrogą dla medycyny, ulegającej trendom superspecjalizacji, ograniczającej pole widzenia patogenezy choroby.

W literaturze medycznej nie mamy dotąd opracowań dotyczących wielkiego wkładu Jana Pawła II w promowanie humanizacji medycyny, „uczłowieczanie” pracy lekarza i miejsca jej wykonywania. Pisze on:

[...] musicie nieustannie wypełniać swój obowiązek w perspektywie ludzkiej osoby i wymagań wypływających z jej godności. [...] Nikt z was nie może być tylko lekarzem danego narządu czy układu, ale winien zająć się całą osobą, więcej - stosunkami międzyosobowymi, które wpływają na jej zdrowie ${ }^{7}$.

${ }^{6}$ Por. abp H. Hoser, Przyszłość i promocja myśli bioetycznej Karola Wojtyły-Jana Pawła II, [w:] Bioetyka pokolenia Karola Wojtyły..., dz. cyt., s. 140.

7 Jan Paweł II, Przemówienie na XV Międzynarodowym Kongresie Federacji Stowarzyszeń Lekarzy Katolickich, 3.10.1982, [w:] Jan Paweł II: Być lekarzem..., dz. cyt., s. 52-53. 
[...] chodzi tu o to, żeby pozostawać w obrębie biologii i medycyny, chodzi o zagrożenie prawa człowieka do życia, wynikające z samych odkryć. Niewątpliwie poznanie naukowe ma swoje prawa, których należy się trzymać, zwłaszcza w medycynie [...]. Jeżeli np. nowa metoda badawcza narusza prawo do życia, stwarza ryzyko jego naruszenia, to nie powinno się uważać jej za dozwoloną, tylko dlatego, że poszerza nasze poznanie [...]. Nauka bowiem nie jest najwyższą wartością, której wszystkie inne miałyby być podporządkowane. Wyżej w hierarchii wartości stoi właśnie osobowe prawo jednostki do życia fizycznego i duchowego ${ }^{8}$.

Bardzo ważną wypowiedź usłyszymy także w czasie spotkania z rektorami polskich uczelni w 2011 roku: „Uniwersytet zatem i każdy inny ośrodek naukowy obok przekazywania wiedzy powinien uczyć [...] rozeznania uczciwości metod badawczych i odwagi rezygnacji z tego, co metodologicznie możliwe, ale etycznie naganne" 9

Natomiast podczas spotkania $\mathrm{z}$ naukowym personelem medycznym w San Giacomo (1980) Jan Paweł II powiedział:

Zwracam się przede wszystkim do Was, Szanowni Lekarze i Profesorowie, którzy razem ze swoimi współpracownikami ponosicie główną odpowiedzialność za chorych, potrzebujących bardziej ludzkiego współczucia i braterskiej życzliwości niż odpowiedzialnego leczenia ${ }^{10}$.

O trwałym znaczeniu przesłania papieża na temat holistycznych założeń opieki nad chorym i potrzebie rozwoju ośrodków opieki duchowej wśród chorych mogą świadczyć liczne artykuły w bieżącej prasie medycznej ${ }^{11}$.

Realizacja tych ponadczasowych postulatów papieża wymagała stworzenia konkretnych warunków współpracy. Wspomnę jedynie o kilku inicjatywach Jana Pawła II, stanowiących instytucjonalne „narzędzia” do rozwoju kontaktów Kościoła z medycyną.

W 1985 roku listem papieskim Dolentium Hominum Jan Paweł II ustanawia Papieską Radę ds. Duszpasterstwa Służby Zdrowia. W Radzie tej zespół lekarzy bierze czynny udział w opracowaniu Karty pracowników służby zdrowia. Powstaje również Papieska Rada Rodziny, której przez wiele lat przewodniczy dr Wanda

8 Jan Paweł II, Przemówienie na Kongresie Włoskiego Stowarzyszenia Medycyny Wewnętrznej i Włoskiego Stowarzyszenia Chirurgii Ogólnej, 27.10.1980, [w:] Jan Paweł II: Być lekarzem..., dz. cyt., s. 52, 59.

9 J. Woy-Wojciechowski, Jan Pawet II i medycyna, dz. cyt., s. 63.

${ }_{10}$ Jan Pawet II: Być lekarzem..., dz. cyt., s. 72.

11 Por. Małgorzata Krajnik, Holistyczna opieka nad chorym - nadzieja dla współczesnej medycyny, „Medycyna Praktyczna” (2017) nr 9, s. 121-124. 
Półtawska. Karta zawierała szereg wskazań o podstawowym znaczeniu dla medycyny, m.in.:

[...] humanizacja medycyny powinna być rozwijana zarówno w zakresie osobowo-zawodowym (relacja lekarz-pacjent), jak również w wymiarze społeczno-politycznym, by bronić w strukturach instytucjonalnych i technologicznych interesów ludzko-chrześcijańskich w społeczności ${ }^{12}$.

Z pewnym opóźnieniem, bowiem dopiero miesiąc temu, ukazała się Nowa Karta Pracowników Służby Zdrowia ${ }^{13}$. Dokument ten powstał dzięki staraniom śp. ks. abp. Zygmunta Zimowskiego, przewodniczącego Papieskiej Rady Duszpasterstwa Służby Zdrowia. Ksiądz arcybiskup podkreślił, że Nowa Karta zachowuje wszystkie przesłania Jana Pawła II, ponadto odnosi się jednak także do współczesnych problemów medycyny, wymiaru sprawiedliwości, solidarności wobec pacjentów oraz dostępu do leków. Na życzenie ks. kard. Dziwisza miałem okazję osobiście przekazać mu propozycje poprawy dostępu do leków, szczególnie dla ludzi ubogich oraz bezdomnych, którymi zajmuję się od wielu lat.

Dalece przewidującą inicjatywą Jana Pawła II było ustanowienie listem apostolskim motu proprio, w dniu 11 lutego 1994 roku, Papieskiej Akademii Pro Vita (Papieskiej Akademii Życia). Jan Paweł II przywiązywał dużą wagę do opiniotwórczej roli przedstawicieli nauki, w tym nauk lekarskich, w rozpatrywaniu problemów bioetyki i medycyny. Dodam, że przewodniczącym PAV został mianowany lekarz, a i wśród członków delegatów z całego świata pokaźną grupę stanowili właśnie lekarze. Także w grupie czterech pierwszych polskich członków rzeczywistych - trzech było lekarzami.

PAV, podejmując problematykę początku życia człowieka, oparła się o badania naukowe wybitnych specjalistów, członków tej Akademii. Wskazywali oni - m.in. w zakresie badań genetycznych i embriologicznych - na bezsporny fakt, iż każdy embrion posiada tę samą naturę ludzką, co dorosły człowiek (embrion nie jest więc potencjalnym człowiekiem, ale człowiekiem rozwijającym się do pełni człowieczeństwa), że człowiek nie staje się człowiekiem, lecz jest człowiekiem od samego początku. W programie Akademii znalazło się wiele tematów nawiązujących do obecnie stosowanych form unicestwiania człowieka, od aborcji do szeroko stosowanej antykoncepcji. Międy innymi należało odnieść się do kontrowersyjnego sta-

12 Zob. Papieska Rada ds. Duszpasterstwa Służby Zdrowia, Karta Pracowników Stużby Zdrowia, Watykan 1995, s. 19.

13 Por. Papieska Rada ds. Duszpasterstwa Służby Zdrowia, Nowa Karta Pracowników Stużby Zdrowia, Katowice 2017. 
nowiska, lansowanego przez skrajnie feministyczne organizacje, iż prawo do aborcji jest prawem wolności jednostki do podejmowania tych drastycznych decyzji.

Nie można jednak pominąć faktu, iż dana jednostka wykorzystuje swoje prawa kosztem prawa do życia drugiego człowieka, niemającego możności zabrania głosu, aby zaprotestować. Jest to więc przykład siły, która staje się w ten sposób racją prawa. Myślę, że ten aksjomat o racji prawa do przemocy brzmi wyjątkowo fałszywie w murach uczelni, której naczelną dewizą jest Plus ratio quam vis.

Poruszający problem chrześcijańskiego odnoszenia się do chorych przedstawia Jan Paweł II lekarzom i całej służbie zdrowia w liście apostolskim Salvifici Doloris o sensie ludzkiego cierpienia (11.02.1984). Papież bardzo głęboko przeżywał spotkania z chorymi ludźmi, szczególnie z nieuleczalnie chorymi dziećmi. Starał się zawsze przynieść im pocieszenie. Na temat zbawczej roli cierpienia mówił też w czasie spotkania z licznie zgromadzonymi chorymi w Krakowie, w kościele oo. franciszkanów (9.06.1997). Z myślą o chorych i cierpiących Jan Paweł II ustanawia (8.05.1992 Światowy Dzień Chorego). Staje się on okazją, aby przypomnieć służbie zdrowia o podstawowych zadaniach medycyny: „w miarę możliwości leczyć, a zawsze zapewnić opiekę"14.

Zbliżając się do końca moich rozważań, nie mogę pominąć niezwykle ważnego dla lekarzy stanowiska Jana Pawła II w kwestii roli sumienia, zwłaszcza wobec ułomności prawa stanowionego. Jeszcze w „czasach krakowskich” kard. Karol Wojtyła był autorem ważnego opracowania, przesłanego do papieża Pawła VI (1969). Pisał w nim: „Sumienie stanowi wiążącą i decydującą normę działania ludzkiego [...]. Funkcja sumienia bowiem polega na określeniu dobra i zła i na jego trafnym odróżnieniu w oparciu o obiektywne prawo moralne"15. Nota bene podobną myśl zawiera nasz Kodeks etyki lekarskiej (art. 4), wyraźnie podkreślający, że „[...] lekarz powinien zachować swobodę działań zawodowych, zgodnie ze swym sumieniem i współczesną wiedzą medyczną"16.

Odrębną sesję w PAV o prawie lekarzy, pielęgniarek, farmaceutów i innych pracowników służby zdrowia do sprzeciwu sumienia prowadziła w Watykanie prof. Alicja Grześkowiak. Problematyka tej sesji dotyczyła nierzadkich konfliktów między sumieniem lekarza a zapisami prawa, w takich przypadkach jak: aborcja, eutanazja, antykoncepcja, sztuczne zapłodnienie, praktyka gender itp. Są to bowiem działania w świetle etyki i moralności chrześcijańskiej nigdy niezaakcepto-

14 Jan Paweł II, Przemówienie na Międzynarodowy Kongres Lekarzy Katolickich, Rzym, 17-20.03.2004, [w:] Jan Paweł II: Być lekarzem..., dz. cyt., s. 70.

${ }_{15}$ List arcybiskupa krakowskiego Karola Wojtyły do papieża Pawła VI, 1969, [w:] Bioetyka pokolenia Karola Wojtyty..., dz. cyt., s. 13-34.

${ }^{16}$ Kodeks etyki lekarskiej, Warszawa 2004, s. 7. 
wane przez papieża i określane jako „grzech społeczny” ${ }^{17}$. Niestety w wielu krajach, zwłaszcza na Zachodzie, wprowadzane są prawa zezwalające na te działania, oparte o skrajny permisywizm i liberalizm. Mnożą się też światowe naciski na wyeliminowanie klauzuli sumienia, w imię haseł neutralności aksjologicznej czy moralnej. W myśl tego rodzaju koncepcji lekarz - nawet wbrew swemu sumieniu - miałby wykonywać wszystko, co dopuszcza lokalne prawo i czego domaga się od niego pacjent.

W imię chrześcijańskich zasad, które głosił papież, nie możemy ulegać tym presjom $^{18}$.

Oto fragment niezwykle cennego pisma, stosunkowo mało znanego, jakie otrzymaliśmy od Jana Pawła II przed Zjazdem Lekarzy obradujących nad Kodeksem Etyki Lekarskiej w 2003 roku:

Wiem, z jak wieloma trudnościami boryka się środowisko lekarskie w naszym Kraju. Tym bardziej wyrażam uznanie dla wysiłków [...], aby podejmować tematy fundamentalne dla godnego wypełniania powołania lekarskiego [...]. Lekarz wie dobrze, że w sytuacji zmagania się o dobro, o zdrowie i życie pacjenta - te kwestie nie mogą być rozwiązywane jedynie na poziomie aktualnie obowiązujących przepisów prawnych ${ }^{19}$.

Także w czasie wizyty w Krakowskiej Klinice Kardiologii w 1997 roku Jan Paweł II powiedział: „[...] Wasz zawód jest godny najwyższego szacunku, jest to misja o nadzwyczajnej wartości, którą najlepiej oddaje słowo p o w oła n i e”20.

Czy polskie środowisko lekarskie, zwłaszcza katolickie, spełniło pokładane w nim nadzieje Jana Pawła II? Powszechnie przekazywane były przez lekarzy naszemu papieżowi wyrazy najgłębszego szacunku, oddania oraz zapewnienia o naszym sprzeciwie wobec szerzącej się kultury śmierci. Co prawda, nie zawsze nasz głos był respektowany przez decydentów, mimo niezliczonych petycji, uchwał, deklaracji wiary podpisywanych przez członków Towarzystw Lekarskich i wielu zespołów specjalistycznych.

17 A. Grześkowiak, Sprzeciw sumienia $w$ odniesieniu do różnych kategorii zawodów zwiazanych z ochrona życia, cz. 2, „Naturalne Planowanie Rodziny” (2007) nr 3-4, s. 22-26.

18 Zob. Z. Chłap, „Dobre obyczaje i godność medycyny”, wykład wygłoszony w ramach sympozjum „Godność w perspektywie nauk” zorganizowanego przez Międzynarodowe Towarzystwo Naukowe Fides et Ratio 7 listopada 2011 r., w ramach Dni Jana Pawła II [maszynopis].

19 Jan Paweł II, Telegram do polskich lekarzy z okazji VII Krajowego Zjazdu Lekarzy poświeconego nowelizacji Kodeksu Etyki Lekarskiej, 20.09.2003, [cyt. za:] Bioetyka pokolenia Karola Wojtyły..., dz. cyt., s. 124.

${ }^{20}$ Ojciec Święty Jan Pawet II do Chorych i Personelu medycznego Kliniki Kardiochirurgii, „Gazeta Lekarska” (1997) nr 7-8(78-79), s. 6-7. 
Przekazywane zapewnienia z pewnością cieszyły Jana Pawła II, który bardzo serdecznie i ciepło odnosił się do licznie odwiedzających go lekarzy, zawsze życzliwie wprowadzanych „na pokoje” przez ks. bp. Stanisława Dziwisza, sekretarza papieża. Ojciec święty był pełen pogody, radził nam, aby nigdy się nie zniechęcać, zawsze mieć ufność i nadzieję w Opatrzności.

Zdarzało się jednak, że brak konkretnych wyników naszych poczynań w zakresie ochrony życia od poczęcia wywoływał pewne zniecierpliwienie Jana Pawła II, który w czasie prywatnych spotkań z lekarzami wołał wzburzony: „Gdzie są pediatrzy! Przecież to nawet nie jest sprawa etyki chrześcijańskiej, ale zdroworozsądkowej"21.

W tamtych latach papież pilnie oczekiwał wieści o akcjach lekarzy w obronie życia. Nie zawsze były to wieści pozytywne. Kiedyś miał nawet powiedzieć: „Zróbcie dobry związek lekarzy katolickich, których opinie musiałby docenić parlament”22.

Może obecne lata przyniosą nam pożądane dobre zmiany, nadzieję na pełne respektowanie godności człowieka w każdym okresie życia.

Wielki papież, św. Jan Paweł II, pozostawił nam, lekarzom, piękną i poruszającą modlitwę do Pana Jezusa, Boskiego Lekarza:

Panie, $[\ldots]$ oświeć nasze umysły i prowadź dłonie,

Spraw, byśmy potrafili Cię naśladować nie tylko jako lekarze ciała,

ale i całego człowieka,

Spraw, byśmy starali się bronić życia od początku do jego naturalnego końca,

Uczyń nas dobrymi Samarytanami,

Błogosław naszej pracy i naszemu zawodowi ${ }^{23}$.

${ }_{21}$ W. Półtawska, Czego oczekiwał Ojciec Święty Jan Paweł II od lekarzy, [w:] Bioetyka pokolenia Karola Wojtyly..., dz. cyt., s. 42.

22 W. Półtawska, Czego oczekiwał Ojciec Święty..., dz. cyt.

23 Jan Paweł II, Modlitwa Lekarza (na Światowy Kongres Lekarzy Katolickich), Rzym 2000, [w:] Jan Paweł II: Być lekarzem..., dz. cyt., s. 149-150. 


\section{Abstract}

\section{John Paul II to doctors}

The meaning of medical vocation and its central role in health service and care for human's life had a very special place in saint John Paul II's both teaching and ministry. The Pope preached constantly about the necessity of building a stable alliance between medicine and the Church in preserving humanity. At the center of his attention was especially collaboration between medicine and pastoral care of the sick, returning medicine to its human dimension, and defense of conscience clause of doctors, so frequently now forced to do whatever any given state law allows, and a patient wants, even if it is against doctor's conscience.

The author reminds how intensely John Paul II stressed dangers stemming from negligence of biological laws of humans life. The Pope admonished scientist that university should teach "recognition of just research methods and courage of declining these which are methodologically possible, but ethically wrong."

The Pope returned frequently in his sermons to the question of human suffering and Christian relation to the sick. He reminded to doctors that one of the most fundamental directives in medical treatment should be to love human being "even there, where others can't love," and should "always be servants of life, and never deliverers of death". 